


\section{PEASANTS IN WORLD HISTORY}

This is the first world history of peasants. Peasants in World History analyzes the multiple transformations of peasant life through history by focusing on three primary areas: the organization of peasant societies, their integration within wider societal structures, and the changing connections between local, regional and global processes.

Peasants have been a vital component in human history over the last 10,000 years, with nearly one-third of the world's population still living a peasant lifestyle today. Their role as rural producers of ever-new surpluses instigated complex and often-opposing processes of social and spatial change throughout the world. Eric Vanhaute frames this social change in a story of evolving peasant frontiers. These frontiers provide a global comparative-historical lens to look at the social, economic and ecological changes within village-systems, agrarian empires and global capitalism. Bringing the story of the peasantry up through the modern period and looking to the future, the author offers a succinct overview with students in mind.

This book is recommended reading to anyone interested in the history and future of peasantries and is a valuable addition to undergraduate and graduate courses in World History, Global Economic History, Global Studies and Rural Sociology.

Eric Vanhaute is Professor in Economic and Social History and World History at Ghent University, Belgium. He has published extensively on agrarian and rural history, the history of labor markets and social inequality, and world history. 


\section{Themes in World History}

Series editor: Peter N. Stearns

The Themes in World History series offers focused treatment of a range of human experiences and institutions in the world history context. The purpose is to provide serious, if brief, discussions of important topics as additions to textbook coverage and document collections. The treatments will allow students to probe particular facets of the human story in greater depth than textbook coverage allows, and to gain a fuller sense of historians' analytical methods and debates in the process. Each topic is handled over time - allowing discussions of changes and continuities. Each topic is assessed in terms of a range of different societies and religions - allowing comparisons of relevant similarities and differences. Each book in the series helps readers deal with world history in action, evaluating global contexts as they work through some of the key components of human society and human life.

\section{Time in World History}

Peter N. Stearns

Migration in World History (Third Edition)

Patrick Manning with Tiffany Trimmer

\section{Agriculture in World History (Second Edition)}

Mark B. Tauger

\section{Happiness in World History}

Peter N. Stearns

\section{Peasants in World History}

Eric Vanhaute

For more information about this series, please visit: https://www.routledge.com 


\section{PEASANTS IN WORLD HISTORY}

Eric Vanhaute 
First published 2021

by Routledge

52 Vanderbilt Avenue, New York, NY 10017

and by Routledge

2 Park Square, Milton Park, Abingdon, Oxon, OX14 4RN

Routledge is an imprint of the Taylor E Francis Group, an informa business

(C) 2021 Taylor \& Francis

The right of Eric Vanhaute to be identified as author of this work has been asserted by him in accordance with sections 77 and 78 of the Copyright, Designs and Patents Act 1988.

All rights reserved. No part of this book may be reprinted or reproduced or utilised in any form or by any electronic, mechanical, or other means, now known or hereafter invented, including photocopying and recording, or in any information storage or retrieval system, without permission in writing from the publishers.

Trademark notice: Product or corporate names may be trademarks or registered trademarks, and are used only for identification and explanation without intent to infringe.

Library of Congress Cataloging-in-Publication Data

Names: Vanhaute, E., author.

Title: Peasants in world history / Eric Vanhaute.

Description: New York, NY : Routledge, 2021.

Series: Themes in world history | Includes bibliographical references

and index. | Subjects: LCSH: Peasants-History.

Classification: LCC HD1521 .V36 2021 (print)

LCC HD1521 (ebook) | DDC 305.5/63309-dc23

LC record available at https://lccn.loc.gov/2020046203

LC ebook record available at https://lccn.loc.gov/2020046204

ISBN: 978-0-415-74093-7 (hbk)

ISBN: 978-0-415-74094-4 (pbk)

ISBN: 978-1-315-81547-3 (ebk)

Typeset in Bembo

by codeMantra 
In memory of my grandparents and the other peasant families that have created the world we live in. 


\section{CONTENTS}

1 Introduction: The Peasant in Each of Us 1

2 New Frontiers: From the First Peasants to Early Agrarian States

3 Extending Frontiers: Agrarian Empires and Their Peasants

4 Interconnecting Frontiers: Imperial Growth, Commercial Expansion and the Peasantization of the World

5 Intensifying Frontiers: The Territorialization of Peasantries and the Final Enclosure

6 Globalizing Frontiers: The Reform of Peasantries in a Neoliberal World

7 The End of Frontiers: The Past and the Future of Peasants 


\section{ACKNOWLEDGMENTS}

This is a book long in the making. As a textbook it is the outcome of many years of reading, teaching, reflecting, writing and rewriting. There is no way that I can do justice to the many sources of knowledge and inspiration that I have used, a heritage brought together over generations. It is impossible to fully acknowledge this heritage, especially in a textbook format without proper referencing. The bibliographic lists at the end of each chapter only very partially meet this gap. This is a frustration, but it is also a gratitude and a satisfaction, since I could be triggered, inspired and propelled by numerous authors, books and papers and by collocutors, activists and movements. I developed some of my arguments in a set of papers, chapters and articles.

My fascination for rural worlds, and how they change before one's eyes started with my youth, spent in the shadow of my grandfather's farm. My work on Flemish peasantries was inspired by the Ghent School of social history, especially Jos De Belder and Hugo Soly. I dedicate this book to my mentor, Jos De Belder.

This book matured during a number of research stays, notably at the Weatherhead Initiative on Global History at Harvard University, at the Re:Work Program (IGK Work and Human Life Cycle in Global History) in Berlin and at the Netherlands Institute for Advanced Study in the Humanities and Social Sciences (NIAS) in Amsterdam. I am especially grateful to their administrative and library staff. I was able to present and discuss my thoughts in a number of workshops and conferences, and I am very much indebted to my colleagues, students, collaborators and audiences for numerous conversations and discussions which contributed to the long-enduring process of reframing and rephrasing. Special thanks go to my colleagues in the Ghent University research group ECC (Economies, Comparisons, Connections), the UGent Center for 
Global Studies, the research network CORN (Comparative Rural History) and the Commodity Frontiers Initiative. I thank Sven Beckert, Esther Beeckaert, Claudia Bernardi, Ulbe Bosma, Dieter Bruneel, Hanne Cottyn, Pieter De Reu, Thijs Lambrecht, John Latham-Sprinkle, Gillian Mathys, Wouter Ronsijn, Mindi Schneider, Erik Thoen, Sven Van Melkebeke, Sven Vrielinck, Wang Yang and many others who gave me tips and advice. They contributed to the book more that they could imagine. Many thanks for Linda Weix for revising my language and Peter Stearns for supporting me all these years.

Antwerp, December 2020 


\section{INTRODUCTION}

\section{The Peasant in Each of Us ${ }^{1}$}

Recognizing also the past, present and future contributions of peasants and other people working in rural areas in all regions of the world to development and to conserving and improving biodiversity, which constitute the basis of food and agricultural production throughout the world, and their contribution in ensuring the right to adequate food and food security.

(From the preamble of the United Nations Declaration on the Rights of Peasants and Other People Working in Rural Areas)

The United Nations General Assembly adopted the Declaration on the Rights of Peasants, officially United Nations Declaration on the Rights of Peasants and Other People Working in Rural Areas (UNDROP), in December 2018. The UN Declaration is a milestone, the result of almost 20 years of negation and mobilization by peasant organizations. It recognizes the long history of discrimination and subordination that has affected peasants and other people working in rural areas for too long. It highlights the central role these people play in today's society and that of tomorrow. The Declaration should be read as a vigorous plea to protect the rights of rural populations, including peasants, fisherfolks, nomads, agricultural workers and indigenous peoples, to improve their legal position and living conditions and to strengthen food sovereignty. States have committed to respect and protect the individual and collective rights of peasants, to promote family farming and peasant agriculture. This book aims to recall 'the past, present and future contributions of peasants' by narrating their story throughout world history.

1 May Sarton, Seen from a Train. Published in Collected Poems, 1930-1993 (New York, 1993). 


\section{Peasant Worlds}

Peasants are still with us. The survival and persistence of peasantries in today's world have confused social scientists for a long time. The demise of peasants was announced time and again by intellectuals, capitalists, reformers and development planners alike. The very notion of peasants and peasantries confronts us with the flaws of traditional/orthodox development stories. The mainstream image of the fate of peasants and peasantries was based on a standard story of the much-commented Western road to capitalist agriculture and the concurrent disintegration of peasant societies. Recent history has shown that the English and European experiences of the dissolution of peasant societies within the context of expanding industrial and welfare economies is not and will not be a general example for the rest of the world. When we look beyond the old premises of westernized development, we see a very different picture. It is a picture of vast family based rural and agricultural economies in which diversified production chains and multiple strategies of risk minimization are pooled together with locally and regionally anchored income and exchange systems. The position of rural societies in the past and the present should not be understood uniquely. Understanding multiple trajectories of peasant change requires new historical knowledge about the role of peasantries during long-term and global economic and social transformations. This book emphasizes that peasantries around the world have followed different trajectories of change and have developed divergent repertoires of accommodation, adaptation and resistance. The expansion of civilizations, states and global capitalism triggered different paths of peasant transformation and different processes of peasantization, depeasantization and re-peasantization.

This book recounts the story of the peasants. We almost exclusively focus on peasants in agricultural societies, as 'the tillers of the earth.' Peasants do not include other people in rural societies such as herders, transhumant pastoralists, nomadic and semi-nomadic people and fisherfolk. This book describes the worlds that peasants have made and their immense diversity. To understand peasant change in a world-historical perspective, we use a set of four interrelated analytical concepts. Peasant worlds are first shaped by the nature of peasant work, as a manifestation of specific labor/land/nature relations. Peasant communities are the central space for organization, self-determination, negotiation and resistance. They are also the gateway to larger and incorporative systems and the locus of what is called the 'peasant question.' Peasant frontiers map the processes of incorporation, adaptation and opposition and explain how peasantries exist through these frontiers. Peasant regimes situate and explain social change, trajectories of transformation in peasant work, peasant communities and peasant frontiers and in a broad time/space context. By unwinding the genealogy of peasant transformation, we can understand and explain the different strategies that peasant populations have developed to defend and secure access to their essential means of production, nature, land and labor throughout world history. 


\title{
Peasant Work
}

The first article of the Declaration on the Rights of Peasants defines a peasant as

\begin{abstract}
any person who engages or who seeks to engage, alone, or in association with others or as a community, in small-scale agricultural production for subsistence and/or for the market, and who relies significantly, though not necessarily exclusively, on family or household labor and other nonmonetized ways of organizing labor, and who has a special dependency on and attachment to the land.
\end{abstract}

Throughout history, peasants have been workers of the land. They live in rural, agricultural households and have direct access to the land they work, either as common users, tenants or smallholders. They are organized in family bonds, village communities and social groups that we call peasantries. These bonds pool different forms of income and meet a significant portion of their subsistence needs via networks of production, exchange, credit and protection. Most of the time, peasantries have been ruled by other social groups that extract a surplus either via rents, market transfers or through control of public power (taxation). Any definition includes these key terms: (a degree of) household and local autonomy, direct access to land and labor resources, flexible strategies of income-pooling, household-based village structures and surplus extraction outside local control. This surplus corresponds with Eric Wolf's 'fund of rent,' which distinguishes the peasant from the 'primitive cultivator.' Differences between peasants, market-driven farmers and industrial or entrepreneurial farming must be understood on a continuum, with land, household labor and the local community as discriminating variables.

Peasantries have been the single most important social group in world history since the advent of agriculture. All successful cultures and civilizations, excluding the nomadic empires, were based on extensive peasant economies comprising 90 percent or more of the population. Today, about one-third of the world's population is still economically dependent on agricultural production; of this, more than 95 percent are smallholders in the Global South. Although in sharp decline over the last century-around 1950 two-thirds of the world's population was engaged in agriculture - the absolute numbers have never been this high. About 2.5 billion people (this equals the total world population in 1950) eke out a living from predominantly peasant-based agriculture. Today the world has more than 600 million agricultural farms, and 85 percent of them are peasant holdings cultivating less than two hectares. It is generally agreed that smallholders still provide the majority of the world's food supply. In some Asian and sub-Saharan regions, this amounts to 70 percent and more.

The minimum social conditions of farming include access to land, labor, tools and seeds. Historically, the principal social units through which the means of farming have been secured are the rural household and the village 
household system, both varying greatly in size, composition and social relations through time and space. For a long time, intellectuals aimed to describe and understand the 'distinctness' of peasant work and to explore the 'essence' of the peasant. Disdain toward the 'louts and oafs' has been part of the discourse of the wealthy, the powerful and the literate in the West for a long time. The dualistic and biased images of rural versus non-rural worlds can be traced back to the origins of the concepts of pagensis/paysan(ne)/paisano(a)/peasant, meaning from the pays, the countryside. In the Anglo-Saxon version, peasant continues to keep its narrow meaning, basically pointing at the era of so-called feudalism and referring to social groups from the (distant) past. Even in its broadest usage, such as campesino(a) in Latin America, peasants have been viewed as survivors of the past. In nineteenth- and twentieth-century modernization thinking, the peasant was a kind of archetypical rural producer that represented the starting point on the axis of evolution: the traditional community as the counterpart of modernity. Western-based historiography has long developed and described the 'anti-modern' model of a 'familistic' (family based) society as a relatively undifferentiated economy of family farms and rural crafts and services, structured by internal agencies such as family, kinship and village.

The rediscovery-in the 1960s and 1970s-of the works of the Russian agrarian economist and rural sociologist Alexander V. Chayanov (1888-1937) triggered a new wave of peasant studies and a renewed debate about the nature of peasant societies. The rural anthropologist Eric Wolf and rural sociologist Theodor Shanin, amongst others, moved this debate beyond a-historical and dichotomist representations. The question is not whether peasants were naturally conservative, values-rational, safety-oriented investors in their land and labor, or whether they tended to be risk-taking, market-oriented maximizers. They were and are both. Quoting Erik Wolf, they are

rural cultivators whose surpluses are transferred to a dominant group of rulers that uses the surpluses both to underwrite its own standard of living and to distribute the remainder to groups in society that do not farm but must be fed for their specific goods and services in return.

That is why peasants only existed within a social formation (peasantries) and within a class relationship (the external subordination to lords, government authorities and/or regional or international markets).

Peasantries made societies; societies made peasantries. Surplus production from nature and the land, in various forms, has been a precondition for largescale societal change. Societal change was necessary to group agricultural producers into peasantries. Agricultural-based economic systems facilitated vaster communal units and extended village networks. This provoked profound changes in the structure of social relations, population growth and village and supra-village institutions. The spread of agricultural village societies as the primary food system took millennia. By 5000 BCE, much of the world's 
population lived by farming; the first agricultural-based empires emerged by 3000 BCE. By then peasant economies had become sufficiently advanced and, in some regions, they supported more complex, urban-based societies and differentiated trade networks. Civilizations did not simply rely on agricultural producers; they also organized, dominated and exploited them. Civilization equated complexity, sophistication, development and grand culture. For peasants, it mostly corresponded to dominion. Sometimes formally free, mostly bound to the soil by their masters, they have almost always been the lowest class or caste, and women, in general, the lowest status among farmers.

Peasant history is the history of peasants' work, of the struggle for the fruits of their labor. Social relations in agricultural societies have been built on the returns of the land. They were reproduced in institutions and norms that defined new rules of ownership, inheritance, transmission and control. Peasantries did not only feed civilizations, empires, states and economies; they also supported their ecological and social resilience and fueled their expansion. They were their socio-ecological frontiers. Farming societies developed a new, more intrusive and aggressive attitude toward the resources of nature, land and labor. The expansion of plant and animal husbandry presumed more radical exploitation of diverse ecosystems and the development of new tools, new modes of reclaiming lands and renewing fertility and new modes of cultivation and animal breeding. This had an increasing impact on human-nature relations, predominantly resulting in massive worldwide deforestation.

\section{Peasant Communities and the Peasant Question}

Like every social formation, peasantries developed as sets of social relationships. The peasant household was the basic economic unit. It pursued an agricultural livelihood by combining subsistence and commodity production through direct access to nature, land, labor and commodities. Households, extended families, kinship and village societies were the vital nodes of production, consumption, reproduction, socialization, welfare, credit and risk-spreading. These social formations were also the peasants' gateway to the broader world.

Throughout history, the communal level has been the central space for self-determination, negotiation and resistance. Communities facilitated the organization, procurement and defense of common goals. The persistence of community systems supported households to intervene in the public sphere in the form of reciprocal mechanisms, authoritative bodies and collective actions. These regulatory structures determined and allocated rights among community members. The combination of safeguarding a minimum of autonomous control over vital resources and securing a minimum of involvement in broader socio-political structures accounted for the peasant communities' multifaceted, apparently contradictory, but above all, alert attitude toward incorporation processes. On the one hand, the defiant stance adopted by peasants was based on an attempt to defend a particular method of regulating access to livelihood 
resources. On the other hand, these groups adopted a pragmatic stance and often adapted or even assimilated to new and incorporating entities. This is reflected in the development of market and trade relations as well as in legalpolitical struggles. Rather than attesting to the group's openness to or craving for market incorporation, this claim to participation should be assessed in the context of the survival guarantees that peasants could obtain from the people who ruled them, usually in exchange for taxation and surplus production. So-called peasant or indigenous resistance included diverse response options sprouting from this 'subversive complicity.' They range from overt to covert, material to cosmologic, institutionalized to symbolic and individual to collective strategies. Peasant resistance should be addressed as a nuanced continuum.

Social scientists have coined the concept of agrarian change to refer to historical processes of absorption of agrarian-rural worlds within broader geographies and non-agricultural sectors, and to subsequent acts of negotiation, adaptation and resistance of agrarian-rural peoples. The process of agrarian change has never been absolute or complete; it created immense disparities on regional and global levels. What was often considered historical processes of de-peasantization were, in essence, part of peasantries' diversified labor and income strategies. Due to intensifying economic and social uprooting, these survival strategies have become more critical than ever for a substantive segment of today's world population. The 'peasant question' has been raised to query the role and fate of peasantries within processes of societal transition toward a capitalist world. Today, in a global context, the socio-economic peasant question (the survival of the peasantry as a separate social class) has become complexly entangled with the socio-cultural indigenous question (indigenousness as a cultural identity). As stated in the Declaration on the Rights of Peasants, the labels 'peasant' and 'indigenous' increasingly refer to a set of claims that coincide or overlap with various other identities (gender, class, linguistic, ethnic, national). Peasant and indigenous identities have become partly overlapping categories of 'peripherality,' an umbrella stigma of the poor and the marginalized in today's globalizing world. The roles of locality and community have been reinforced; sometimes they are reinvented as a basic framework for both peasant and indigenous identities. Battles related to the peasant and indigenous claims to land, territory and resources, which usually have a communal rather than an individual nature, have been a central instigator. For peasantries, land has been and still is the primary basis of negotiation and interaction with other sectors of society because its use has direct implications for their exchange positions (products derived from that land) and their power relations (the regulation of access to the land).

\section{Peasant Frontiers and Peasant Regimes}

Peasantries have been vital frontiers of civilizations, empires and globalizing capitalism. We define frontiers as constantly shifting processes of contact 
between different spaces and social systems. Frontier expansion nourished social systems; it provided new sources of nature, land and labor, creating new supplies, reducing production costs and increasing profitability. Environmental historian and historical geographer Jason W. Moore defined these frontiers not as fixed geographical places, but as socio-ecological relations "that unleash a new stream of nature's bounty to capital: cheap food, cheap energy, cheap raw materials, and cheap labor." They generated moving sets of local activities to secure access to labor and land for extra-local commodity production (primarily agricultural, forest and mining goods). The sites where this happened became frontier zones. Frontiers have never been fixed; they have always been inherently unstable. They challenged the limits of social, economic and ecological sustainability, resulting in the apparent need to be continually shifting in time and space. The incorporation of rural zones and the creation of new peasantries have been central to the expansion of village societies, early states, agrarian (tributary) empires, and global (colonial, imperialist and neoliberal) capitalism. In most societal settings, these zones became integrated as loci of appropriation of the produce of land and labor and as peripheral spaces of production, exploitation and recreation. Peasantries have been primary frontiers in societal expansion. Their partial incorporation as producers of new surpluses instigated mixed, complex and often opposing processes of social and spatial change, generating a multiplicity of frontier zones. Capitalist incorporation and expansion were fueled by the opening of the 'Great Frontier,' a metaphor for an intensifying and interconnected worldwide set of moving frontiers. Global capitalist expansion since the long sixteenth century demanded a drastic increase in the world-ecological surplus. Hybrid cultures originated along the margins of social and economic systems; social groups and spatial zones were incorporated or excluded. The frontier perspective grasps the imbalances of incorporation processes, emphasizing the role of the peoples living in the margins and friction zones.

Agrarian change and peasant transformation have often been framed in dichotomous and predominantly a-historical models. Market versus nonmarket relations, economic versus cultural forms of exchange, modern versus traditional societal arrangements; a long tradition of rural sociology is grafted upon these dichotomies. Concepts such as traditional, survival, subsistence or informal economies have not been very helpful in understanding social change in a world-historical context. They freeze peasant's history in dualistic frames and fail to grasp the dynamics and change within peasant societies. When survival and subsistence refer to living at a bare-bone level with little or no surpluses, peasant economies do not fit these typologies. On the contrary, they were rooted in a wide variety of reciprocal exchanges: redistributions that integrated different spaces in networks of mutual obligations, regional and extra-regional market transactions, and public retributions. Peasant change has often been understood from a post-hoc perspective. It got its meaning from the outcomes that we measured. Agrarian and farming systems have been 
an influential ordering tool in agricultural and rural history. These systems have been understood as historically constituted and geographically localized types of agriculture and ecological and social (re)production systems, with a strong focus on ecology, technology and farming practices. As an addition and critique, social-ecological agrosystems concentrated on rural production networks as sets of region-specific social power relations shaping the economic reproduction of a given geographical area. Still, in a global-comparative context, these typologies were frequently based on Eurocentric models and understood in predetermined historical sequences. Bottom-up research shows that agrarian and peasant regimes cannot be predicted from environmental, demographic or evolutionary contexts.

In order to make sense of social change in a broad time/space span, we frame social realities into a genealogy of evolving and changing peasant regimes. Peasant regimes are a tool to contextualize and understand how peasantries in a particular time/space are (internally) organized and (externally) embedded. Each regime embodies an institutionalization of economic, social, political, cultural and ecological forces that structure internal and external peasant relations. They organize forms and relations of production, reproduction, exchange and extraction. They define how these relations are ordered and represented (or legitimized) via structures of power and forms of hegemony. Regimes have to be understood as methodological tools to specify changing relations between 'world ordering' and peasantries. A genealogy of peasant regimes claims that episodes of restructuring and transition are bounded by more stable periods of regulation and organization, albeit in a non-determined way. The genealogy of societal regimes provides a genuine, global comparative-historical lens to look at the social, economic, political and ecological relations of agrarian empires and global capitalism. It aims at a non-hierarchical, non-evolutionary and non-deterministic interpretation of global social change.

\section{A History of Peasants}

This book aims to map and understand the multiple trajectories of peasant transformation in world history. Three interlocking dimensions constitute peasant history: the organization of peasant societies (household and kinship relations, village systems, regional networks), their integration within broader societal structures (trade and commerce networks, fiscal systems, power and property relations), and the changing connections between local, regional and global processes. Power relations within and between communities define the way labor, land and nature have been accessed and used. These include relations of property and tenure between owners of the land, users of the land and governors of the land; between landlords, peasants and governments. Property rights have been central to the emanation of social power relations within different types of peasant regimes. The outcome of the configuration of power relations 
and the social distribution of land and labor have differed wildly over time and space. The variety of land-labor relations reflects the frontier position and the communal base of peasant regimes.

World-historical research is integrated, comparative and systemic. The worlds of peasants are understood within their world-historical coordinates as part of systemic transformations on a regional and a global scale. This ambition presents specific challenges. A chronological narrative has to stress regional differences and varying time scales, illustrating different speeds of change. Peasant regimes and their time indications are never absolute since they tend to overlap. Chapter 2, New Frontiers, covers the millennia from the first peasants to the first agrarian states around 3000 BCE. Early village societies (from 7000 BCE), city-states, and agrarian-imperial expansion (from 3000 BCE) framed the first types of peasant regimes. Despite huge differences in time and space, they flourished well into the second millennium CE. The story of agrarian empires is mainly covered in Chapter 3, Extending Frontiers. Agrarian empires were defined by gradual peasant incorporation, indirect political control and coerced extraction of land and labor surpluses via taxes, tributes, rents and confiscations. The invention of private property and the commodification of the countryside marked the beginning of capitalist expansion, which accelerated in the long sixteenth century. Imperial and commercial expansion is the central focus of Chapter 4, Interconnecting Frontiers. Capitalist expansion changed the rules of the game; peasant regimes were premised on new forms of enclosure of land and labor. Direct incorporation thoroughly altered ecological relations, resulting in a further diversification of systems of access to nature, land and labor, of systems of production and reproduction and of survival and coping mechanisms. Chapter 5, Intensifying Frontiers, tells the story of the global enclosure from the eighteenth century CE. Uneven incorporation and uneven commodification caused further social and spatial differentiation through divergent processes of de-peasantization and re-peasantization, and a concurrent diversification of peasant livelihood. Chapter 6, Globalizing Frontiers, questions the impact of these processes on the position of peasants in the world of neoliberal globalization since the 1970s. We conclude this book with an epilogue (Chapter 7) on current and future peasants and question whether we are approaching the end of frontiers.

We refer mostly to world regions, sometimes using contemporary country indications. Time is expressed in BCE and CE.

\section{Selected Readings}

Some parts of this introduction have been published in:

Sven Beckert, Ulbe Bosma, Mindi Schneider and Eric Vanhaute, "Commodity Frontiers and the Transformation of the Global Countryside. A Research Agenda", Journal of Global History, 2021 
Eric Vanhaute, "Agriculture," Handbook the Global History of Work, eds Karen Hofmeester and Marcel Van der Linden: 217-235 (Berlin and Boston: De Gruyter, 2017)

Eric Vanhaute and Hanne Cottyn, "Into Their Land and Labours : A Comparative and Global Analysis of Trajectories of Peasant Transformation," ICAS Review Paper Series $(8,2017)$

On peasants and peasants' work:

Henri Bernstein, Class Dynamics of Agrarian Change (Halifax and Winnipeg: Fernwood, 2010)

Tom Brass, Peasants, Populism, and Postmodernism. The Return of the Agrarian Myth (London: Routledge, 2000)

CORN Publication Series (Comparative Rural History of the North Sea Area; Turnhout: Brepols, 1999-2018; 16 vols); Rural economy and society in north-western Europe, 500-2000 (Turnhout: Brepols, 2010-2015), 4 volumes (Erik Thoen et al. eds, Struggling with the Environment: Land Use and Productivity (2015); Eric Vanhaute et al. eds, Making a Living: Family, Income and Labour (2012); Bas van Bavel et al. eds, Social Relations: Property and Power (2010); Leen Van Molle et al. eds, The Agro-Food Market: Production, Distribution and Consumption (2013))

Frank Ellis Frank, Peasant Economics: Farm Households in Agrarian Development (Cambridge: Cambridge University Press, 1993)

Eric J. Hobsbawm et al. (eds), Peasants in History. Essays in Honour of Daniel Thorner (Oxford: Oxford University Press, 1980)

Catarina Lis and Hugo Soly, Worthy Efforts. Attitudes to Work and Workers in Pre-Industrial Europe (Leiden: Brill, 2012)

James C. Scott, The Moral Economy of the Peasant: Rebellion and Subsistence in Southeast Asia (New Haven, CT and London: Yale University Press, 1976)

James C. Scott, Seeing like a State. How Certain Schemes to Improve the Human Condition Have Failed (New Haven, CT: Yale University Press, 1998)

Teodor Shanin, Peasants and Peasant Societies. Selected Readings (Oxford and New York: Basil Blackwell, 1987)

Statistics: FAOSTAT Database [http://faostat.fao.org]

Marcel Van der Linden, Workers of the World. Essays toward a Global Labor History (Leiden and Boston, MA: Brill, 2008).

Eric R. Wolf, Peasants (Englewood Cliffs, NJ: Prentice-Hall, 1966)

On agrosystems and regimes:

Paul Brassley and Richard Soffe, Agriculture. A Very Short Introduction (Oxford: Oxford University Press, 2016)

Erich Landsteiner and Ernst Langthaler, eds, Agrosystems and Labour Relations in European Rural Societies (Middle Ages-Twentieth Century) (Turnhout: Brepols, 2010)

Philip McMichael, Food Regimes and Agrarian Questions (Halifax and Winnipeg: Fernwood Publishing, 2013).

Guy Robinson, Geographies of Agriculture. Globalisation, Restructuring and Sustainability (Harlow: Pearson, 2004)

Erik Thoen, “'Social Agrosystems' as an Economic Concept to Explain Regional Differences. An Essay Taking the Former County of Flanders as an Example (Middle Ages-19th Century)', Landholding and Land Transfer in the North Sea Area (Late Middle Ages-19th Century), eds B.J.P. Van Bavel and P. Hoppenbrouwers, 47-66 (Turnhout: Brepols, 2004) 
On frontiers:

Edward B. Barbier, Scarcity and Frontiers. How Economies Have Developed Through Natural Resource Exploitation (Cambridge: Cambridge University Press, 2011)

Richard Manning, Against the Grain. How Agriculture Has Hijacked Civilization (New York: North Point Press, 2004)

Jason W. Moore, Capitalism in the Web of Life. Ecology and the Accumulation of Capital (London and New York: Verso, 2015)

Raj Patel and Jason W. Moore, A History of the World in Seven Cheap Things: a Guide to Capitalism, Nature and the Future of the Planet (Oakland: University of California Press, 2017)

Mindi Schneider, Sven Beckert, Ulbe Bosma and Eric Vanhaute (eds), Commodity Frontiers. Capitalism, Contestation, and the Transformation of the Global Countryside. The Journal of the Commodity Frontiers Initiative (https://commodityfrontiers.com/journal) Jules Pretty, Agri-culture. Reconnecting People, Land and Nature (London: Earthscan, 2002) 